\title{
Control of hydrogen sulphide in full-scale anaerobic digesters using iron (III) chloride: performance, origin and effects
}

\author{
D Erdirencelebi ${ }^{1 *}$ and M Kucukhemek ${ }^{2}$ \\ 'Selcuk University, Environmental Engineering Department, Konya, Turkey \\ ${ }^{2}$ Konya Water and Sewerage Administration, Konya, Turkey
}

\begin{abstract}
The study presents the results of sulphide control using iron (III) chloride in full-scale anaerobic digesters (ADs) at a largescale municipal wastewater treatment plant (WWTP). Iron (III) ('ferric') chloride was applied at a range of $24-105 \mathrm{mg} \mathrm{FeCl} / \mathrm{L}$ with and without alkali solution using different strategies. Introduction points were implemented at the feeding line and the sludge thickener unit. Response of the ADs in terms of biogas $\mathrm{H}_{2} \mathrm{~S}$ reduction over time, solid loading rates (SLR), feed sludge flow rate and $\mathrm{pH}$ level were investigated. Reduction of $\mathrm{H}_{2} \mathrm{~S}$ in the biogas reached $4035 \mu \mathrm{g} / \mathrm{L}$ in directly-dosed $\mathrm{AD}$ versus a $1345 \mu \mathrm{g} / \mathrm{L}$ drop in non-dosed ADs, as a result of internal recirculation among the digesters, where actual values were possibly higher as volatile solid (VS) degradation increased in all ADs during the dosing period. No noticeable effect on biogas production and $\mathrm{pH}$ was observed. The degree of $\mathrm{H}_{2} \mathrm{~S}$ production was found to be correlated to the volatile SLR, where primary sludge solids contributed mostly to the organic and proteinaceous content of the thickened sludge and presented a high variation and a strong relationship with $\mathrm{H}_{2} \mathrm{~S}$ production. Correlation analysis based on data for the 17 -month period that followed supported the significant role of primary SLR in $\mathrm{H}_{2} \mathrm{~S}$ production.
\end{abstract}

Keywords: biogas, hydrogen sulphide, anaerobic digester, control, solids, full-scale

\section{INTRODUCTION}

Unionized hydrogen sulphide $\left(\mathrm{H}_{2} \mathrm{~S}\right)$ produced in the biogas of anaerobic digesters (ADs) needs to be reduced to a low level before it reaches electric generators, gas storage units and machines in biogas applications, in order to eliminate corrosion. It can be removed from the biogas via dry or wet oxidation processes (Deublein and Steinhauser, 2008). Desulphurization of the biogas as it leaves the anaerobic reactor is a measure towards the protection of electric generators and metal equipment on the biogas line, whereas the removal of $\mathrm{H}_{2} \mathrm{~S}$ in the $\mathrm{AD}$ liquid offers several advantages, such as methane augmentation and protection of the reactor's material and metal equipment from intensive corrosion (Yu et al., 2015). As ADs are tightly insulated, large-scale reactors, replacement of any metal equipment or maintenance of concrete walls/ceiling are highly problematic and costly, and require long periods of time to make the repairs and bring the reactors back into operation (Erdirencelebi et al., 2015). The break-up of interior equipment or crown corrosion may go unnoticed over a period of time (Erdirencelebi et al., 2015). Long-term maintenance requirements present the weakest point of anaerobic digestion, which is crucially important in the renewable energy field. Additionally, design capacity of the biogas desulfurization unit is usually based on the biogas production rate and may be underestimated in $\mathrm{H}_{2} \mathrm{~S}$ removal capacity terms in wastewater treatment plants (WWTPs) (Erdirencelebi et al., 2015). The sulphate content of the raw inlet wastewater is one source for sulphide produced in the ADs, whereas the protein content can be a more significant factor for strong-character municipal wastewaters or in cases of industrial wastewater intrusion (Stams et al., 2003; Adams et al., 2003).

To whom all correspondence should be addressed.

Tiri

$+27903322238677$

e-mail:dbaktil@hotmail.com

Received 20 January 2017; accepted in revised form 14 March 2018
Micro-aeration of the ADs, both in the headspace or liquid, has been shown to convert $\mathrm{H}_{2} \mathrm{~S}$ to sulphate via sulphideoxidizing bacteria at lab-scale (Van der Zee et al., 2007) and pilot-scale (Diaz et al., 2010; Ramos and Fdz-Polanco, 2014). Pure oxygen is delivered to the headspace or recirculation flow at very low ratios. One disadvantage is the production of sulphate in the presence of $\mathrm{H}_{2} \mathrm{O}$ in the form of sulfuric acid, which may cause crown corrosion on the AD's concrete walls and ceiling in the long term. The process has not been shown to be applicable yet in the long term in full-scale digesters. Oxidation of sulphide to elemental sulphur in the headspace at sufficiently low aeration levels may be an alternative at a minimal cost, but the reaction has a lower energy yield compared to sulphate production, is closely dependent on $\mathrm{pH}$, hard to control and unstable for sulphur production (Janssen et al., 1998).

The ability to reduce $\mathrm{H}_{2} \mathrm{~S} / \mathrm{HS}$ - in the digester liquid and biogas using iron (III) salts is an effective alternative. Ferric iron reacts by reduction to ferrous iron (iron (II)) and forms an insoluble precipitate:

$$
\begin{aligned}
& 2 \mathrm{Fe}^{3+}+\mathrm{S}^{2-} \rightarrow 2 \mathrm{Fe}^{2+}+\mathrm{S}^{0} \\
& 2 \mathrm{Fe}^{3+}+3 \mathrm{HS}^{-} \rightarrow \mathrm{Fe}_{2} \mathrm{~S}_{3}+3 \mathrm{H}^{+}
\end{aligned}
$$

These reactions indicate a 'stoichiometric' dose of $1.17-3.5 \mathrm{~g} \mathrm{Fe}^{3+}$ per $\mathrm{g}$ of sulphide, making $2.27-6.82 \mathrm{~g} \mathrm{FeCl}_{3}$ per $1 \mathrm{~g}$ of sulphide. The addition of iron salts is an effective way of removing sulphide from anaerobic effluents (Johnson and Hallberg, 2005). It is also an effective reducer of odours originating from volatile sulphurous compounds and has been reported to promote volatile solid (VS) digestion when added prior to anaerobic digestion (Higgins, 2010; Novak and Park, 2010). The amount of sulphide removed depends on several parameters, such as $\mathrm{pH}, \mathrm{ORP}$ and temperature (Speece, 1996; Ali et al., 2015). The $\mathrm{H}_{2} \mathrm{~S}$ reduction in the biogas is a result of equilibrium chemistry between $\mathrm{H}_{2} \mathrm{~S}(\mathrm{~g}), \mathrm{H}_{2} \mathrm{~S}(\mathrm{aq})$ and $\mathrm{HS}^{-}$(aq), where partial pressure, $\mathrm{pH}$ and temperature will be 
the effective parameters (Speece, 1996; Appels et al., 2008). Chemical requirement, response of the $\mathrm{AD}$ and its duration can be determined accurately if based on full-scale applications. Feeding, internal recirculation and mixing characteristics of the $\mathrm{AD}$ systems with multiple reactor configurations require specific on-site applications. This technique also promotes methanogenesis, thus, methane production, as iron is an essential trace element for methanogenic bacterial growth and is reduced to insufficiently low levels due to precipitation with sulphide produced under usual operating conditions (Speece, 1996; Yu et al., 2015). Solid $\mathrm{FeCl}_{3}$ is highly soluble in aqueous medium $\left(0.92 \mathrm{~g} / \mathrm{mL}\right.$ at $\left.20^{\circ} \mathrm{C}\right)$ and also delays dissimilatory sulphate reduction as it also accepts other electrons during metabolism (Lar and Li, 2009).

In the present study, iron (III) chloride dosing on full-scale parallel ADs was investigated at different levels and patterns to determine the degree of $\mathrm{H}_{2} \mathrm{~S}$ reduction in the biogas, the time for $\mathrm{AD}$ response to the dosing level and the effect of additional alkali dosing. Several parameters, such as $\mathrm{pH}$, VS degradation and biogas production of the ADs, volatile solid (VS) concentration of the thickened sludge, solid loading rates (SLRs) and organic nitrogen/total Kjeldahl nitrogen (TKN) content of the primary and secondary (waste biological sludge (WBS)) sludge and feed sludge flow rate were also investigated in the period following $\mathrm{H}_{2} \mathrm{~S}$ control and their degree of correlation with hydrogen sulphide production was determined.

\section{MATERIALS AND METHODS}

Konya WWTP (Turkey) is a large-scale plant serving an equivalent population of 1.2 million and receives wastewaters of municipal and industrial origins at an average flow rate of $160000 \mathrm{~m}^{3} / \mathrm{d}$. The plant consists of primary and secondary treatment (modified Bardenpho) units on the main line. Four $7000 \mathrm{~m}^{3}$ active volume completely-mixed ADs with $17-20 \mathrm{~d}$ retention time generate an approximate $70 \%$ of the energy requirement of the WWTP. The design of the plant has been made according to German Association for the Water Environment (ATV) 1000 standards. ADs are mixed via a shaft and receive an average total flow rate of $1400 \mathrm{~m}^{3}$ per day. The plant's desulfurization unit consists of a sulphide-oxidizing biofilter. The projected $\mathrm{H}_{2} \mathrm{~S}$ concentration in the biogas of the WWTP was $1880-2020 \mu \mathrm{g} / \mathrm{L}$ and the design of the biological desulfurization unit was made for a capacity of $1000 \mathrm{~m}^{3} / \mathrm{hr}$ flow-rate and $1750 \mu \mathrm{g} / \mathrm{L} \mathrm{H}_{2} \mathrm{~S}$ removal by the designer firm.
Metal salt dosing at $24-105 \mathrm{mg} \mathrm{FeCl} / \mathrm{L}$, with and without alkali $(\mathrm{NaOH})$ addition, to the $\mathrm{AD}$ feed flows was the method chosen to reduce $\mathrm{H}_{2} \mathrm{~S}$ in the $\mathrm{ADs}$. Iron salt $\left(\mathrm{FeCl}_{3} 41-42 \%\right.$ aqueous solution (Akkim Kimya, TR)) was introduced first into the feed line of the thickened sludge via a dosage pump. Alkali addition was aimed to raise/balance $\mathrm{pH}$ against acidity increase after the ferric chloride addition and promote the equilibrium reaction to proceed, so as to reduce $\mathrm{H}_{2} \mathrm{~S}$ and increase HS in the aqueous phase. After a 4 -week period, the dosing point was changed to the thickener unit at a tripled amount. Five different strategies of dosing were implemented at variable duration for a period of 6 months from January to July, 2011 (Table 1). Change in feeding dose was applied according to the level and stabilization of $\mathrm{H}_{2} \mathrm{~S}$ in the biogas. An optimum chemical dosage range was targeted, but an unexpected maintenance and halfcapacity period on the main-line was experienced during the study. Reduction in $\mathrm{H}_{2} \mathrm{~S}$ concentration was calculated based on the initial level of $8070 \mu \mathrm{g} / \mathrm{L}$. One $\mu \mathrm{g} / \mathrm{L}$ corresponds to 1.345 times part per million (ppm) of $\mathrm{H}_{2} \mathrm{~S}$.

Hydrogen sulphide $\left(\mathrm{H}_{2} \mathrm{~S}\right)$ was measured in the biogas in duplicate samples as a daily routine by the laboratory staff of the facility via a titrimetric method (4 500-S $\mathrm{S}^{2-} \mathrm{C}-\mathrm{F}$ ) according to standard methods (APHA, 2005). Hydrogen sulphide immobilized as $\mathrm{ZnS}$ in the alkaline zinc acetate solution was titrated via iodometric method. Other parameters evaluated in relevance to anaerobic digestion and $\mathrm{H}_{2} \mathrm{~S}$ production were: TKN (4 500- org $_{\text {org }}$ ), TS/VS (2 540-Solids-B-E) of the raw wastewater, primary, secondary and thickened sludge (APHA, 2005). The $\mathrm{pH}$ was measured on-line via a $\mathrm{pH}$ meter installed on the recirculation pipeline.

Several monitored parameters via on-line monitoring and analyses on the sludge line (solid loading rates (SLR) $(\mathrm{kg} / \mathrm{d})$ of waste biological sludge (WBS) and primary sludge (PS), feed sludge flow rate $\left(\mathrm{m}^{3} / \mathrm{d}\right)$, thickened sludge VS concentration $(\mathrm{mg} / \mathrm{L})$, digester temperature $\left({ }^{\circ} \mathrm{C}\right)$ and biogas production $\left(\mathrm{m}^{3} / \mathrm{d}\right)$ were evaluated for their degree of correlation with biogas $\mathrm{H}_{2} \mathrm{~S}$ concentration in the 17-month period that followed (from July 2011 to November 2012). Pearson's correlation was used and coefficients were calculated via IBM SPSS Statistics 23. The correlation coefficient $(R)$ is a statistical measure of the strength of a linear relationship between two variables with positive values denoting positive linear correlation and negative values denoting negative linear correlation where closeness to 1 or -1 shows the increasing strength of the linear correlation.

\begin{tabular}{|l|c|c|c|c|c|}
\hline \multicolumn{7}{|c|}{$\begin{array}{c}\text { TABLE 1 } \\
\text { Summary of the chemical dosing strategies (L:level) }\end{array}$} \\
\hline Strategy & $\begin{array}{c}\text { Duration } \\
\text { (d) }\end{array}$ & $\begin{array}{c}\text { Iron (III) chloride dose in } \\
\text { the feed sludge } \\
\text { (mg FeCl } / \text { L) }\end{array}$ & $\begin{array}{c}\text { Iron (III) chloride dose in } \\
\text { the feed sludge** } \\
\text { (g FeCl } / \text { /kg VS) }\end{array}$ & $\begin{array}{c}\text { Dosed AD } \\
\text { (\#) }\end{array}$ & $\begin{array}{c}\text { Sodium hydroxide dose } \\
\text { (mg/L) }\end{array}$ \\
\hline S1 & 12 & 50 & 2.63 & 3 & - \\
\hline S2-L1 & 15 & 30 & 1.58 & $1-4$ & - \\
\hline S2-L2 & 20 & 43 & 2.15 & $1-4$ & - \\
\hline S2-L3 & 42 & 24 & $1.20,1.02$ & $1-4$ & - \\
\hline S3 & 40 & 24 & 0.84 & $1-4$ & 60 (AD2) \\
\hline S4 & 23 & 44 & 1.69 & 2,4 & 60 (AD2) \\
\hline S5 & 30 & 30 & 1.04 & 2,4 & - \\
\hline
\end{tabular}

${ }^{*}$ Line-1 of the Bardenpho unit was shut down, ${ }^{* *}$ based on average VS concentration in the feed sludge 


\section{RESULTS}

Konya WWTP was brought into operation in September 2010, and from the start biogas $\mathrm{H}_{2} \mathrm{~S}$ reached 8070 and $6050 \mu \mathrm{g} / \mathrm{L}$ in the gas and desulfurization outlets, respectively. Designed capacity of the desulfurization unit was exceeded 4 times in the ADs during full operation. This level was unacceptable for the electric generators and the biogas was burned via a flame unit so as to protect the metal equipment and engines. Quick action to reduce the $\mathrm{H}_{2} \mathrm{~S}$ became urgent.

\section{Iron salt dosing: pattern and effects on $\mathrm{H}_{2} \mathrm{~S}$ reduction}

Iron (III) chloride dosing was started at $50 \mathrm{mg} \mathrm{FeCl}_{3} / \mathrm{L}$ in the feed sludge to AD3 only, because operators needed to be cautious with full-scale application as iron chloride is a coagulant used in sludge thickening and might have caused clogging and/or acidic effect in the feeding pipes (Tchobanoglous et al., 2003). As a result, reduction in $\mathrm{H}_{2} \mathrm{~S}$ by $3360 \mu \mathrm{g} / \mathrm{L}$ or $39 \%$ (down to $4170 \mu \mathrm{g} / \mathrm{L}$ ) occurred gradually over a period of 12 days (Stra-S1 (Table 1)) (Fig. 1). As each feed flow to the ADs was mixed with all the digesters' sludge at the inlet of the reactor, iron chloride added to one digester was distributed to all the ADs gradually, and consequently $\mathrm{H}_{2} \mathrm{~S}$ was reduced to some degree $(1345 \mu \mathrm{g} / \mathrm{L}$ as $16 \%)$ in the non-dosed digesters. Consequently, reduced dosing at $30 \mathrm{mg} \mathrm{FeCl} / \mathrm{L}$ was started to all digesters (Stra-S2-L1) due to concern over the coagulating effect of iron chloride. This resulted in a slower reduction from $6860( \pm 140)$ to $5510( \pm 140) \mu \mathrm{g} / \mathrm{L}$ in all $\mathrm{ADs}$ in $15 \mathrm{~d}$. The increase to $43 \mathrm{mg} \mathrm{FeCl} / \mathrm{L}$ dosing implemented for further reduction reduced the level down to $3560 \mu \mathrm{g} / \mathrm{L}(24 \%)$ (Stra-S2-L2). Lower dosing $\left(24 \mathrm{mg} \mathrm{FeCl}_{3} / \mathrm{L}\right)$ continued for $82 \mathrm{~d}$ (Stra-S2-L3 and Stra-S3) resulted in a rise in biogas $\mathrm{H}_{2} \mathrm{~S}$ level to a large range of $4040-4980 \mu \mathrm{g} / \mathrm{L}$ (38-50\% reduction). During this period (March) the average VS concentration reached 23 $500 \mathrm{mg} / \mathrm{L}$ in the thickened sludge as AD4 was taken into full capacity operation inducing a rise in both solid load and average VS concentration to the thickeners and ADs, respectively, which was observed to be correlated to the high fluctuation pattern in the biogas $\mathrm{H}_{2} \mathrm{~S}$ concentration (Stra-S2-L2/3) (Fig. 1-3(a)). Apparently, the final dosing level appeared insufficient to control and reduce $\mathrm{H}_{2} \mathrm{~S}$ at full capacity $\mathrm{AD}$ operation.

Additional $\mathrm{NaOH}$ dosing at $60 \mathrm{mg} / \mathrm{L}$ in the feed to AD2 did not produce any significant effect on either the $\mathrm{H}_{2} \mathrm{~S}$ level or pH during this period (Stra-S3) (Fig. 1, 3b). A 23-day shutdown period of the Bardenpho Unit Line-1 between 27 March and 18 April resulted in a delayed and significant decrease of biogas $\mathrm{H}_{2} \mathrm{~S}$ to the 1350-1 $900 \mu \mathrm{g} / \mathrm{L}$ level and near the design value of desulfurized biogas, $27 \mathrm{~d}$ from the start of maintenance. Primary SLR seemed to be a more effective source of $\mathrm{H}_{2} \mathrm{~S}$ production when the reduction degree was considered, where secondary SLR was accordingly reduced to half (Fig. 3-a). The effect of the maintenance period was observed as a $2600 \mu \mathrm{g} / \mathrm{L}$ reduction in the feed sludge's monthly average VS concentration in May (Fig. 2).

Further strategies consisted of increasing the iron salt and alkali application to different ADs to observe any significantly

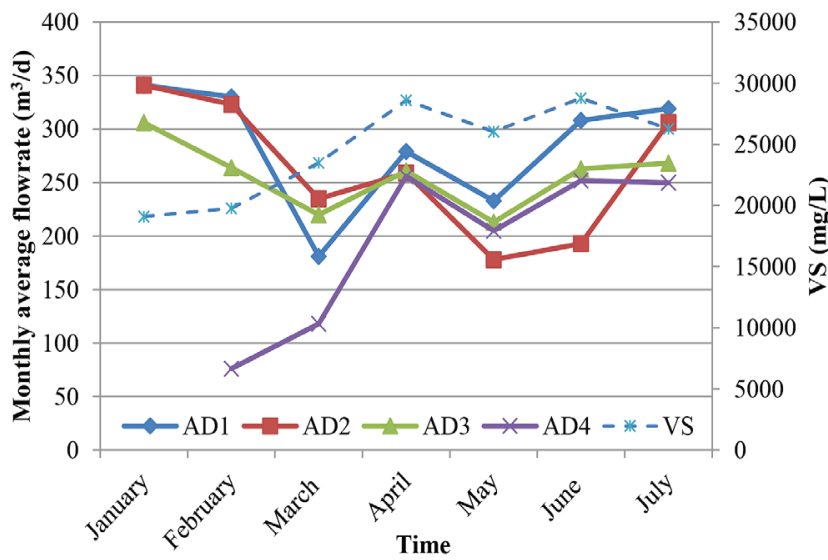

Figure 2

Change in monthly flow rates and average volatile solid (VS) in the thickened sludge fed to the full-scale ADs

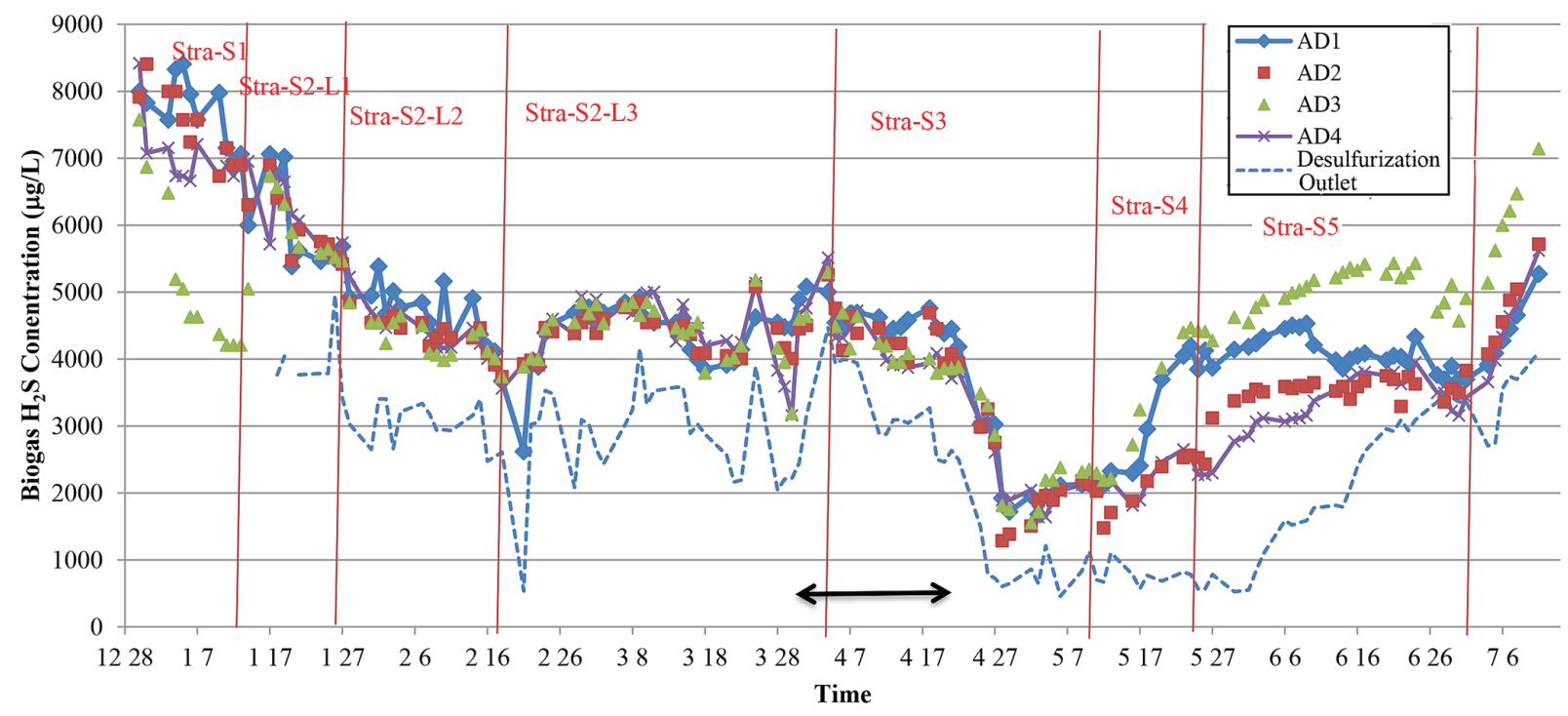

Figure 1

Change in hydrogen sulphide concentration in the full-scale ADs biogas and in the effluent biogas from desulfurization unit during different dosing strategies (black arrow shows the shut-down period of Bardenpho Unit Line-1 due to maintenance) 
different pattern among the ADs. During Stra-S4, AD2 was dosed with alkali and iron chloride and AD4 only with iron chloride. The new strategy's effect was observed at the end of $15 \mathrm{~d}$ with $\mathrm{H}_{2} \mathrm{~S}$ rising to $4040-4400 \mu \mathrm{g} / \mathrm{L}$ (46-50\% reduction) in the non-dosed ADs, with $70-72 \%$ reduction in the $\mathrm{FeCl}_{3}$ receiving ADs (Fig. 1). Primary SLR increased gradually to 160 t/d (orange arrow in Fig. 3-a). No difference due to alkali addition was observed between AD2 and AD4.

In the last strategy (S5), the dosage of the ADs (2 and 4) was reduced to $30 \mathrm{mg} \mathrm{FeCl}_{3} / \mathrm{L}$ and $\mathrm{AD} 1$ was restarted with $\mathrm{FeCl}_{3}$ dosing at a higher level $\left(105 \mathrm{mg} \mathrm{FeCl}_{3} / \mathrm{L}\right)$ to observe the reaction time to reach $\mathrm{AD} 2$ and $\mathrm{AD} 4 \mathrm{H}_{2} \mathrm{~S}$ levels, which apparently took $21 \mathrm{~d}$ (Fig. 1). A primary SLR at $200 \mathrm{t} / \mathrm{d}$ resulted in higher feed VS concentration $(28800 \mathrm{mg} / \mathrm{L})$ during the period, and the combined effect with reduced dosing increased the biogas $\mathrm{H}_{2} \mathrm{~S}$ in $\mathrm{AD} 2$ and $\mathrm{AD} 4$ by up to $3800 \mu \mathrm{g} / \mathrm{L}$ (50-53\% reduction) (Figs 1 and 3-a). An increase in primary SLR also increased biological unit MLSS concentration (data not shown here) and secondary SLR, as the primary settling capacity was exceeded
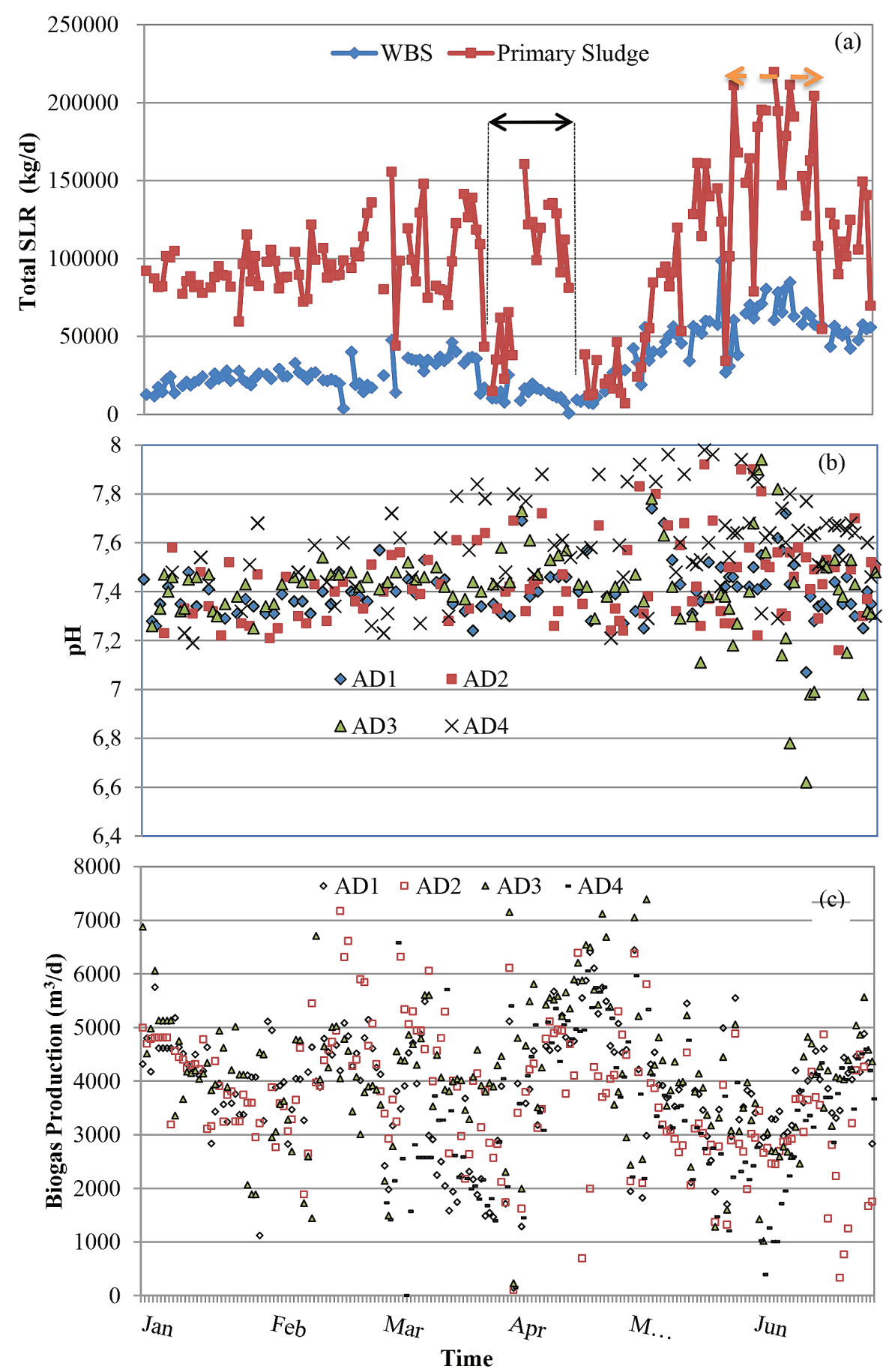

Figure 3

Change in primary and secondary (WBS) SLRs (a), $\mathrm{pH}$ (b) and biogas production (c) in ADs between January and June 2011 (solid arrow: shut-down period of Bardenpho Unit Line-1; dotted arrow: high primary sludge TS loading period) 
(orange arrow in Fig. 3-a). This was mostly induced by the weather with heavy rains during the period.

The $\mathrm{pH}$ level remained between 7.2 and 7.9 in all ADs during January-June 2011 and no significant effect was observed on $\mathrm{pH}$ due to chemical dosing (Fig. 3-b). Biogas production proceeded on a large scale and with a fluctuating pattern and presented no noticeable response to iron chloride dosing in the study period, as presented in Fig. 3-c, and no apparent change after the dosing period (data not shown).

As a linear relation was established between the dosage at the applied range $\left(20-50 \mathrm{mg} \mathrm{FeCl}_{3} / \mathrm{L}\right.$ ) and reduced $\mathrm{H}_{2} \mathrm{~S}(\mathrm{~g})$ $\left(y=49.472 x+744.45 R^{2}=0.9282\right)$, which was calculated based on a range of $7000-8070 \mu \mathrm{g} / \mathrm{L}$ of initial $\mathrm{H}_{2} \mathrm{~S}$ concentration, for which a range of 4.14-5.64 $\mathrm{g} \mathrm{FeCl}_{3}$ per $\mathrm{g}$ of liquid sulphide removed was obtained. The Henry constant of $2650 \mathrm{mg} / \mathrm{L} \mathrm{H}_{2} \mathrm{~S}$ in the liquid per atmosphere of $\mathrm{H}_{2} \mathrm{~S}$ (gas) at $35^{\circ} \mathrm{C}$ was used to determine sulphide removed in the liquid phase (Speece, 1996).

Nitrogen analyses conducted on primary and secondary sludge evidenced a significantly higher protein content in primary sludge (Fig. 4). TKN varied from $2500-4000 \mathrm{mg} / \mathrm{L}$ $\mathrm{N}$, a wide range, compared to a stable level of $1000 \mathrm{mg} / \mathrm{L}$ TKN

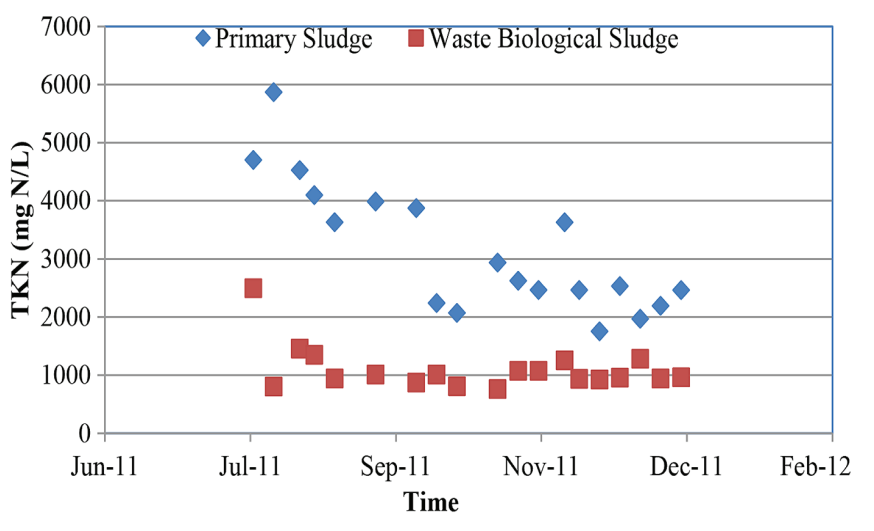

Figure 4

TKN content of the primary and secondary sludge between July and December 2011 for secondary sludge. The organic nitrogen ratio in the influent raw wastewater was $54-74 \%$ for a range of total nitrogen at $152-269 \mathrm{mg} / \mathrm{L}$ TKN during May-June 2011. This ratio is subject to increase in primary solids as proteinaceous matter will tend to settle and concentrate whereas ammonium nitrogen will be transported in the liquid form to the consequent unit on the main line. Additionally, primary sludge's VS content at $72-75 \%$ and its significantly higher concentration range of $22000-33000 \mathrm{mg} / \mathrm{L}$ were found to be more influential on the VS content of the thickened sludge.

An increased degree of VS degradation was also observed in this study as the 18-month data were plotted for the periods following and prior to the dosing of the ADs (Fig. 5). A second high level observed just after the maintenance period does not reflect a real increase as it shows accumulative removal of the biomass digested in the ADs over the maintenance period (not a steady state result). Regarding Konya WWTP ADs, the actual sulphide removal was probably higher than the observed degree, due to augmented VS/protein degradation.

The desulfurization unit had a fluctuating performance with $\mathrm{H}_{2} \mathrm{~S}$ removal over a wide range $(540-2020 \mu \mathrm{g} / \mathrm{L}$ ) (Fig. 1). Higher removal and stability became noticeable with the start of the hot season, indicating the temperature effect and need for autotrophic sulphide oxidation. A second observation indicated that the present desulfurization unit met the design value at half the capacity of the WWTP with $\mathrm{FeCl}_{3}$ addition at $40 \mathrm{mg} / \mathrm{L} \mathrm{FeCl}_{3}$.

\section{Statistical correlation analysis}

Primary and secondary SLRs, feed sludge flow rate and VS concentration, temperature and biogas production were considered as the input parameters and their correlation coefficients are presented in Table 2. Regarding the coefficients, the first and second most influential parameters on the formation of biogas $\mathrm{H}_{2} \mathrm{~S}$ content were determined as the primary and secondary SLRs. The primary sludge effect was meaningful and supported previous findings. Negative numbers indicated that influent flow rate, temperature and feed VS concentration increased biogas production, and, therefore, decreased $\mathrm{H}_{2} \mathrm{~S}$ concentration (by dilution) in the biogas.

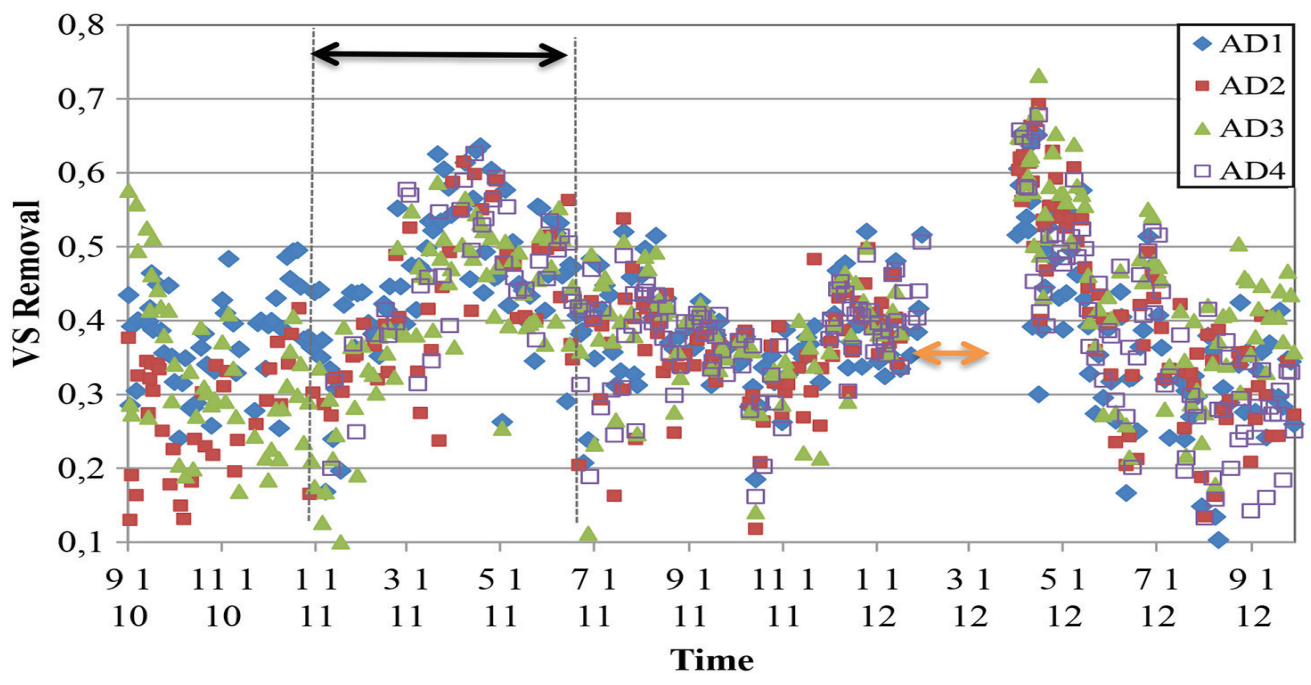

Figure 5

VS removal for the 18-month period of the $A D s$ (black arrow: $\mathrm{FeCl}_{3}$ dosing period; orange arrow:maintenance period of $A D s$ ) 
TABLE 2

Pearson correlation coefficients between the input parameters and biogas $\mathrm{H}_{2} \mathrm{~S}$ concentration

\begin{tabular}{|l|l|l|l|l|l|l|}
\hline & $\begin{array}{l}\text { WBS* } \\
\text { SLR }\end{array}$ & $\begin{array}{l}\text { PS** } \\
\text { SLR }\end{array}$ & $\begin{array}{l}\text { Thickened sludge } \\
\text { flow rate }\end{array}$ & $\begin{array}{l}\text { Thickened sludge } \\
\text { volatile solid } \\
\text { concentration }\end{array}$ & Temperature & $\begin{array}{l}\text { Biogas } \\
\text { produced }\end{array}$ \\
\hline $\begin{array}{l}\text { Biogas } \mathrm{H}_{2} \mathrm{~S} \\
\text { concentration }\end{array}$ & 0.375 & 0.429 & -0.197 & -0.213 & -0.014 & -0.314 \\
\hline
\end{tabular}

${ }^{*}$ Waste biological sludge, ${ }^{* *}$ primary sludge, ${ }^{* * *} \mu \mathrm{g} / \mathrm{L}$

As biological treatment units are operated at high stability and long retention times in WWTPs, the most influential parameter that can destabilize both activated sludge and anaerobic digestion units is expected to be the primary solids in cases of overloading (Erdirencelebi and Kucukhemek, 2015). A change in its characteristics over the daily, monthly or seasonal scale may cause disturbances in plant operation. Figure 6 (a) was constructed to present primary sludge SLR's high fluctuation pattern and effect on $\mathrm{H}_{2} \mathrm{~S}$ in the following period. Biogas production followed a similar pattern to the feed VS loading rate values (Fig 6 (b)). Feed VS loading rate and biogas production proceeded over a wide but stable range, whereas the $\mathrm{H}_{2} \mathrm{~S}$ profile indicated a closer relationship with primary SLR fluctuation.

\section{DISCUSSION}

Sulphide removal in the biogas at full-scale WWTP was necessary during the first year of plant operation as the design value of the desulfurization unit was not met by the actual $\mathrm{H}_{2} \mathrm{~S}$ level reaching the electric generators. AD's response to dosing was stabilized quite fast after an approximately 11-day period. The linear relation established between the dosage and reduced $\mathrm{H}_{2} \mathrm{~S}$ (g) gave a range of $4.14-5.64 \mathrm{~g} \mathrm{FeCl}_{3}$ per $\mathrm{g}$ of liquid sulphide removed which was in the range of stoichiometric dose of 2.27-6.82 $\mathrm{g} \mathrm{FeCl}_{3}$ per $1 \mathrm{~g}$ of sulphide.

As Fe (II) and Fe (III) effectively remove dissolved sulphide and $\mathrm{H}_{2} \mathrm{~S}$, their usage has become a common control strategy (Speece, 1996; Abatzoglou and Boivin, 2009; Ali et al., 2014). A disadvantage is the iron consumption by other reactions in the liquid phase. Despite this phenomenon, precipitation with
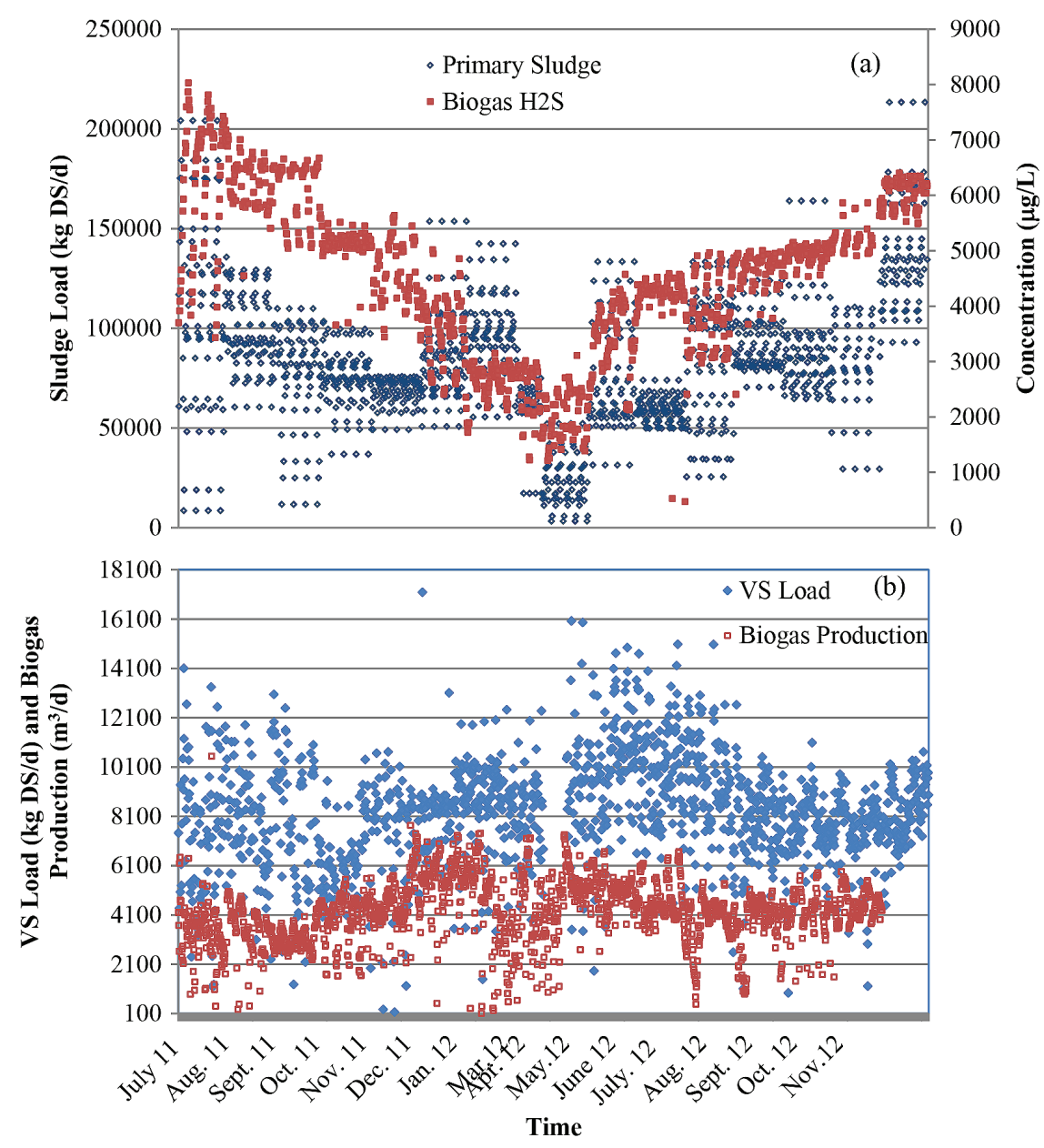

Figure 6

Primary sludge SLR and biogas $\mathrm{H}_{2}$ S content (a) and feed VS loading rate and biogas production (b) of the ADs from July 2011 to November 2012 
sulphide will be the major sink. Removal of sulphide followed an increasing linear relation up to a dosage of $50 \mathrm{mg} / \mathrm{L} \mathrm{Fe}^{3+}$ and a decreasing and non-linear pattern at $50-200 \mathrm{mg} / \mathrm{L} \mathrm{Fe}^{3+}$ (Choi and Rim, 1991). Another benefit of iron salt addition was the increase in COD removal in their high sulphate removal study of glutamic acid waste.

In another current study, Ali et al. (2015) obtained sulphide removal gradually from $10.95 \mathrm{mg} / \mathrm{L} \mathrm{S}$ (aq) to a level of $0-1.7 \mathrm{mg} / \mathrm{L} \mathrm{S}$ (aq) at a $\mathrm{FeCl}_{3}$ dosing range of $20-30 \mathrm{mg} / \mathrm{L}$ in the liquid phase of a pilot UASB reactor.

Hydrogen sulphide production is mostly correlated with sulphate reduction and sulphate-reducing bacteria activity in anaerobic environments (Fedorovich et al., 2003; Appels et al., 2008; Carrera-Chapela et al., 2016). In the case of anaerobic sludge digesters, hydrolysis of the proteinaceous matter is more likely to be a major source of dissolved and gaseous hydrogen sulphide species. In the present investigation, a linear relation at a significant power was observed between primary solids and biogas $\mathrm{H}_{2} \mathrm{~S}$ concentration at full-scale plant. The outcome supports the need for deeper consideration of primary sludge structure as hydrolysis of proteins is a completed reaction in the ADs whereas sulphate may not be reduced totally as a higher number of limiting conditions exist for sulphate-reducing bacteria in their competition with methanogens (Erdirencelebi and Ozturk, 2006).

$\mathrm{FeCl}_{3}$ 's promoting effect observed on VS degradation at real-scale AD operation was reported and verified previously in anaerobic digestion of mixed waste sludge (Park et al., 2006; Novak et al., 2007; Novak and Park, 2010). Adams et al. (2007) observed a parallel increasing pattern of the odorous volatile organic sulfur compounds indicating a correlation between iron and protein degradation. Novak and Park (2010) showed enhanced degradation of VS and improved dewaterability when ferric chloride was dosed to mixed sludge before feeding to ADs. These important findings indicate that iron chloride addition is a beneficial method for improved anaerobic sludge stabilization and final quality. Corrosion control for $\mathrm{H}_{2} \mathrm{~S}$ will also lessen the odour intensity originating from the process and products.

\section{CONCLUSIONS}

Iron (III) chloride dosing at $24-50 \mathrm{mg} / \mathrm{L} \mathrm{FeCl}_{3}$ of all four digesters provided a significant reduction but was not sufficient. As the study period ended, the management decided to replace the desulfurization unit with a higher capacity one as higher dosing would lead to coagulation effect and possible plugging in the sludge feeding lines.

Results obtained in the real-scale study can be summarized as:

- Iron (III) chloride efficiently reduced $\mathrm{H}_{2} \mathrm{~S}$ level in the biogas in a period of $11-15 \mathrm{~d}$ when dosed at $43-105 \mathrm{mg} / \mathrm{L} \mathrm{FeCl}_{3}$ in the feed sludge. Dosing at a $43-50 \mathrm{mg} / \mathrm{L} \mathrm{FeCl}_{3}$ level provided a biogas $\mathrm{H}_{2} \mathrm{~S}$ reduction at $4000-4300 \mu \mathrm{g} / \mathrm{L}$ from a start-up level of $7800-8070 \mu \mathrm{g} / \mathrm{L}$.

- Dosing of one digester reduced other digesters' biogas $\mathrm{H}_{2} \mathrm{~S}$ level indirectly due to the internal mixing in the feeding of ADs. The degree of removal of $\mathrm{H}_{2} \mathrm{~S}$ differed depending on VS and TS loading of the ADs. $50 \mathrm{mg} / \mathrm{L} \mathrm{FeCl}_{3}$ dosing reduced 4000 and $1340 \mu \mathrm{g} / \mathrm{L}$ directly and indirectly, respectively, at feed (thickened) sludge VS concentrations below $20000 \mathrm{mg} / \mathrm{L}$, whereas $105 \mathrm{mg} / \mathrm{L} \mathrm{FeCl}_{3}$ dosing was necessary for the same reduction at $25000-28000 \mathrm{mg} / \mathrm{L}$ VS level.
- Primary sludge SLR was found to be correlated with high $\mathrm{H}_{2} \mathrm{~S}$ in the biogas as the most influential parameter. Its TKN content and SLR showed a highly fluctuating pattern and proved that it deserves more thorough investigation for sulphide control of anaerobic sludge digesters.

- An increase in VS removal degree was observed in all ADs during the dosing period which indicated that the actual sulphide removal was higher than the observed level due to enhanced VS degradation.

- The biological desulfurization unit exhibited a need for heating. It was concluded that biogas heat was not sufficient for the autotrophic activity of the biofilter during cold season.

\section{REFERENCES}

ABATZOGLOU N and BOIVIN S (2009) A review of biogas purification processes. Biofuels Bioprod. Bioref. 3 42-71. https://doi. org/10.1002/bbb.117

ADAMS GM, WITHERSPOON JR, ERDAL ZK, FORBES RH, HARGREAVES JR, HIGGINS, MJ, McEWEN DW and NOVAK JT (2007) Identifying and controlling the municipal wastewater odor environment Phase 3: Biosolids processing modifications for cake odor reduction. Water Environment Research Foundation, Report No.03-CTS-9T. WERF Alexandria, VA.

ALI M, SINGH NK, BHATIA A, SINGH S, KHURSHEED A, KAZMI AA (2015) Sulfide production control in UASB reactor by addition of iron salt. J. Environ. Eng. 141 (6) 06014008/1-4.

APHA (2005) Standard Methods for the Examination of Water and Wastewater. American Public Health Association, Washington, DC. 1216 pp.

APPELS L, BAEYENS J, DEGREVE J and DEWIL R (2008) Principles and potential of the anaerobic digestion of waste-activated sludge. Progress Energ. Combust. Sci. 34 755-781. https://doi.org/10.1016/j. pecs.2008.06.002

CARRERA-CHAPELA F, DONOSO-BRAVO A, JEISONC D, DIAZ I, GONZALEZ JA and RUIZ-FILIPPI G (2016) Development, identification and validation of a mathematical model of anaerobic digestion of sewage sludge focusing on $\mathrm{H}_{2} \mathrm{~S}$ formation and transfer. Biochem. Eng. J. 112 13-19. https://doi.org/10.1016/j.bej.2016.03.008

CHOI E and RIM JM (1991) Competition and inhibition of sulfate reducers and methane producers in anaerobic treatment. Water Sci. Technol. 23 (7-9) 1259-1264.

DEUBLEIN D and STEINHAUSER A (2008) Biogas from Waste and Renewable Resources: An Introduction. Wiley-VCH, Weinheim. 578 pp. https://doi.org/10.1002/9783527621705

DIAZ I, LOPES AC, PEREZ SI and FDZ-POLANCO M (2010) Performance evaluation of oxygen, air and nitrate for the microaerobic removal of hydrogen sulphide in biogas from sludge digestion. Bioresour. Technol. 101 7724-7730. https://doi. org/10.1016/j.biortech.2010.04.062

ERDIRENCELEBI D and OZTURK I (2006) A comparative study of sulfidogenic and methanogenic activities during the treatment of landfill leachate:Part I. J. Environ. Sci. Health Part A 41 687-701. https://doi.org/10.1080/10934520600575093

ERDIRENCELEBI D and KUCUKHEMEK M (2015) Diagnosis of the anaerobic reject water effects on WWTP operational characteristics as a precursor of bulking and foaming. Water Sci. Technol. 71 (4) 572-579. https://doi.org/10.2166/wst.2014.528

ERDIRENCELEBI D, KÜÇÜKHEMEK M and SARI S (2015) Havasız (anaerobik) çamur çürütücülerde karşılaşılan işletim problemleri ve çözüm önerileri (operational problems and solutions coupled to anaerobic sludge digesters). Selcuk Univ. J. Eng. Sci. Technol. 3 (3) 51-58.

FEDOROVICH V, LENS P and KALYUZHNYI S (2003) Extension of Anaerobic Digestion Model No. 1 with processes of sulfate reduction. Appl. Biochem. Biotechnol. 109 (1-3) 33-45. https://doi. org/10.1385/ABAB:109:1-3:33

HIGGINS MJ (2010) Evaluation of aluminum and iron addition during conditioning and dewatering for odor control Phase IV. Water Environment Research Foundation, Report No.03-CTS-9A. WERF, Alexandria, VA. 
JANSSEN AJH, MEIJER S, BONTSEMA J and LETTINGA G (1998) Application of the redox potential for controling a sulfide oxidizing bioreactor. Biotechnol. Bioeng. 60 (2) 147-155. https://doi.org/10.1002/ (SICI)1097-0290(19981020)60:2<147::AID-BIT2>3.0.CO;2-N

JOHNSON DB and HALLBERG KB (2005) Acid mine drainage options: A review. Sci. Total Environ. 338 (1-2) 3-14. https://doi. org/10.1016/j.scitotenv.2004.09.002

LAR JS and LI X (2009) Removal of $\mathrm{H}_{2} \mathrm{~S}$ during anaerobic bioconversion of dairy manure. Chin. J. Chem. Eng. 17 (2) 273-277. https://doi.org/10.1016/S1004-9541(08)60205-0

TCHOBANOGLOUS G, BURTON FL and STENSEL HD (2003) Wastewater Engineering: Treatment, Disposal and Reuse.McGraw Hill Press, New York.

NOVAK JT, VERMA N and MULLER CD (2007) The role of iron and aluminum in digestion and odor formation. Water Sci. Technol. 56 (9) 59-65. https://doi.org/10.2166/wst.2007.705

NOVAK JT and PARK CM (2010) Effect of aluminum and iron on odors, digestion efficiency, and dewatering properties. Report 03-CTS-9b, WERF, IWAP. ISBN: 978-1-84339-283-5/1-84339-2836. https://doi.org/10.2166/9781780403557

PARK CM, ABU-ORF MM, MULLER C and NOVAK JT (2006) The effect of cations on activated sludge characteristics: analysis and effects of iron and aluminum in floc. Water Environ. Res. 78 (1) 31-40. https://doi.org/10.2175/106143005X84495

RAMOS I and FDZ-POLANCO M (2014) Microaerobic control of biogas sulphide content during sewage sludge digestion by using biogas production and hydrogen sulphide concentration. Chem. Eng. J. 250 303-311. https://doi.org/10.1016/j.cej.2014.04.027 SPEECE RE (1996) Anaerobic Biotechnology for Industrial Wastewaters. Archae Press, Nashville.

STAMS AJM, OUDE ELFERINK SJWH and WESTERMANN P (2003) Metabolic interactions between methanogenic consortia and anaerobic respiring bacteria. Adv. Biochem. Eng./Biotechnol. 81 31-56. https://doi.org/10.1007/3-540-45839-5_2

VAN DER ZEE FP, VILLAVERDE S, GARCIA PA and FDZPOLANCO F (2007) Sulfide removal by moderate oxygenation of anaerobic sludge environments. Bioresour. Technol. 98 518-524. https://doi.org/10.1016/j.biortech.2006.02.011

YU B, ZHANG D, SHAN A, LOU Z, YUAN H, HUANG X, YUAN W, DAIC X and ZHU N (2015) Methane-rich biogas production from waste activated sludge with the addition of ferric chloride under a thermophilic anaerobic digestion system. RSC Adv. 5 38538-38546. https://doi.org/10.1039/C5RA02362A 